\title{
Expression and clinical significance of WWOX, Elf5, Snail1 and EMT related factors in epithelial ovarian cancer
}

\author{
YAKUN HU ${ }^{1 *}$, YUCHEN YAN $^{2 *}$, YANG XU ${ }^{3}, \mathrm{HE} \mathrm{YANG}^{3}$, LISHA FANG $^{3}$ \\ YONGLI LIU ${ }^{4}, \mathrm{XIN} \mathrm{LI}^{5}$, QIANG LI ${ }^{6}$ and HONGCHAO YAN ${ }^{3,6}$ \\ ${ }^{1}$ Graduate School and ${ }^{2}$ Department of Clinical Medicine, Xuzhou Medical University, Xuzhou, Jiangsu 221004; \\ ${ }^{3}$ Department of Gynaecology and Obstetrics, The Affiliated Hospital of Xuzhou Medical University; \\ ${ }^{4}$ Department of Gynaecology, Xuzhou No. 1 People's Hospital Affiliated to Xuzhou Medical University, \\ Xuzhou, Jiangsu 221002; ${ }^{5}$ Department of Gynaecology, Xuzhou Maternal and Child Health Care \\ Hospital Affiliated to Xuzhou Medical University, Xuzhou, Jiangsu 221009; ${ }^{6}$ Xuzhou Medical \\ University Science Park Co. Ltd., Xuzhou, Jiangsu 221000, P.R. China
}

Received May 20, 2019; Accepted November 5, 2019

DOI: $10.3892 / \mathrm{ol} .2019 .11213$

\begin{abstract}
Expression and clinical significance of WW domain-containing oxidoreductase (WWOX), Elf5, Snail1 and epithelial-mesenchymal transition (EMT) related factors in epithelial ovarian cancer were investigated. Ovarian cancer tissues of 300 epithelial ovarian cancer patients and the adjacent normal tissues were analyzed. Immunohistochemical method was used to detect the expressions of WWOX, Elf5, Snail1 and EMT marker molecules in the specimens. The relationship between the indicators and clinicopathological parameters, and prognosis of patients with ovarian cancer was analyzed. The relationship between WWOX, Elf5, Snail1 and EMT marker molecules E-cadherin, $\mathrm{N}$-cadherin and vimentin in ovarian cancer tissues was analyzed. The expression levels of WWOX, Elf5, Snail1 and EMT marker molecules in epithelial ovarian cancer tissues were significantly different from those in adjacent normal tissues, and were related to surgical pathological stage, pathological grade and lymph node metastasis. High expressions of WWOX and Elf5 were related to the survival rate of patients. The survival rate of patients with positive expression was significantly higher than that of negative expression. FIGO stage, pathological grade, lymph node metastasis and expression of WWOX and Elf5 were all independent factors affecting postoperative prognosis
\end{abstract}

Correspondence to: Dr Hongchao Yan, Department of Gynaecology and Obstetrics, The Affiliated Hospital of Xuzhou Medical University, 99 Huaihai West Road, Xuzhou, Jiangsu 221002, P.R. China

E-mail: hneb26@163.com; 1015058194@qq.com

*Contributed equally

Key words: ovarian cancer, epithelial-mesenchymal transition, WWOX, Elf5, Snail1 in ovarian cancer patients. In conclusion, the expression levels of WWOX, Elf5, Snaill and EMT related factors in epithelial ovarian cancer tissues are consistent and different. The expression levels of WWOX and Elf5 are related to the survival and prognosis of patients with epithelial ovarian cancer.

\section{Introduction}

The mortality rate of epithelial ovarian cancer (EOC) ranks the first in female malignant tumors because of its hidden location, complicated pathogenesis, lack of early diagnosis and poor therapeutic effect (1). With the development of molecular biology, early screening indicators and biotherapeutic targets can be obtained by exploring the molecular mechanism of ovarian cancer development, which is of great significance for clinical diagnosis and treatment. WW domain-containing oxidoreductase (WWOX) gene is a potential tumor suppressor gene isolated and identified by Płuciennik et al (2) using shotgun gene sequencing technology. Many experimental studies have shown that WWOX expression deletion is closely related to the occurrence and development of a variety of cancers, including ovarian cancer (3). In this study, immunohistochemistry was used to detect the expression levels of WWOX, Elf5, Snail1 and EMT-related proteins in ovarian cancer tissues and to analyze their relationship with clinicopathological features. Correlation between WWOX and Elf5 expression levels and patient prognosis was further analyzed to explore the link between the tumor suppressor gene WWOX and the invasion and metastasis of ovarian cancer and the prognosis of patients from a clinical perspective.

\section{Materials and methods}

Sources of information. In total 300 EOC paraffin embedding specimens of cancer tissue and corresponding normal ovarian tissues adjacent to each tumor (both normal tissues $2 \mathrm{~cm}$ away from the tumor edge, confirmed by pathology) were collected from 2010 to 2013, in the Gynaecology Department 
of Xuzhou No. 1 People's Hospital and Xuzhou Maternal and Child Health Care Hospital. Both hospitals are affiliated to Xuzhou Medical University. The surgical procedures were: tumor cytoreductive surgery (full uterus and double attachment + selective pelvic and abdominal aortic lymph node removal + omentectomy + appendectomy). Exclusion criteria: Patients with other systemic malignancies, metastatic cancers (including primary double cancer) from other organs of the reproductive system, or those who accepted chemotherapy, radiotherapy, or endocrine therapy as first treatment. All cases were complete with clinical, pathological and follow-up data. The selected patients were followed up until the patient died or January 2018. The follow-up period was 6-96 months. The enrolled patients were aged 17-74 years, with a median age of 53 years, 146 cases were $\geq 53$ years, and 154 cases $<53$ years. FIGO criteria: 143 cases of early stage (FIGO I + II stage), 157 cases of advanced stage (FIGO III + IV stage). The degree of differentiation: high differentiation + moderate differentiation (G1 + G2): 124 cases, poor differentiation (G3): 176 cases; pathological type: 168 cases of serous ovarian cancer, 63 cases of mucinous ovarian cancer, 54 cases of endometrial cancer, 15 cases of clear cell carcinoma; lymph node metastasis: 186 cases with metastasis, 114 cases without metastasis. In the same time period, the corresponding 300 adjacent normal tissues were selected as the control group. The study was approved by the Ethics Committee of Xuzhou No. 1 People's Hospital Affiliated to Xuzhou Medical University and Xuzhou Maternal and Child Health Care Hospital Affiliated to Xuzhou Medical University (Xuzhou, China). Informed consents were obtained from patients and their families.

Reagent. Rabbit anti-human WWOX polyclonal antibody, rabbit anti-human Snaill polyclonal antibody, rabbit anti-human E-cadherin polyclonal antibody, rabbit anti-human $\mathrm{N}$-cadherin polyclonal antibody and rabbit anti-human vimentin polyclonal antibody were purchased from Wuhan Proteintech Biotechnology Co., Ltd., rabbit anti-human Elf5 polyclonal antibody was purchased from Beijing Bioss Biotechnology Co., Ltd., Hypersensitive Rabbit Two-Step Detection Kit (PV-9001) and DAB Colorimetric Kit were purchased from Beijing Zsjq Biotechnology Co., Ltd.

Experimental methods. According to the grouping, all collected tissue samples were fixed with $4 \%$ neutral methanol, embedded in paraffin, and serially sectioned at $4 \mu \mathrm{m}$. The sections were dried and immersed in xylene for dewaxing and underwent dehydration of gradient ethanol. After citrate high-pressure antigen retrieval, the specimen was incubated in $3 \%$ hydrogen peroxide for $10 \mathrm{~min}$ at room temperature to block endogenous peroxidase. Six kinds of antibody dilutions (1:100) were added dropwise, incubated at $4^{\circ} \mathrm{C}$ overnight, and rewarmed at room temperature for $1 \mathrm{~h}$, then added to the hypersensitive rabbit two-step test kit, incubated at $37^{\circ} \mathrm{C}$ for $20 \mathrm{~min}$, and developed with DAB. After counterstaining, conventional dehydration, and neutral gum seals, the staining results were observed under a microscope.

Determination of results. Independent double-blind readings were performed by two experienced pathologists to determine immunohistochemical staining results. All marker expression results were scored by the second scoring method based on the intensity of staining and the percentage of positive cells. Coloring intensity: colorless: 0 point; light yellow: 1 point; yellow: 2 points; brown yellow: 3 points. Percentage of positive cells: 10 high power fields (x400 times) were randomly selected from each sample, 100 cells were observed in each high power field, and the percentage of positive cells in each high power field was counted: $<5 \%$ : 0 point; $5-25 \%$ : 1 point; $26-50 \%$ : 2 points; 51-75\%: 3 points; $>75 \%$ : 4 points, the median value was selected. The score of the staining intensity was added to the score of the percentage of positive cells, $\leq 3$ was negative, and $\geq 4$ was positive.

Statistical analysis. Data analysis was performed using SPSS20.0 statistical software. The relationship between the expression of WWOX, Elf5, Snaill, E-cadherin, N-cadherin and vimentin in epithelial ovarian cancer tissues and corresponding adjacent tissues and the expression of various factors and clinicopathological parameters was detected by $\chi^{2}$ test; the relationship between WWOX and Elf5, WWOX, Snaill and EMT marker factors and the positive expression between Elf5, Snaill and EMT marker factors was determined by McNemar test; the relationship between WWOX and Elf5 and survival prognosis was examined by Kaplan-Meier survival analysis, and Cox multivariate regression model was used to analyze the factors affecting prognosis. $\mathrm{P}<0.05$ was considered statistically significant.

\section{Results}

Expression of WWOX, Elf5, Snaill and EMT-related proteins in EOC tissues and adjacent normal tissues. WWOX was expressed in cytoplasm, Elf5 was expressed in the nucleus, Snail1 was expressed in the nucleus and cytoplasm, E-cadherin was expressed in the cell membrane, $\mathrm{N}$-cadherin was expressed in the cell membrane and cytoplasm, and vimentin was expressed in the cytoplasm as brownish yellow particles (Fig. 1). The expression of WWOX, Elf5, Snail1, E-cadherin, $\mathrm{N}$-cadherin and vimentin were different in ovarian cancer and adjacent normal tissues, and the difference was statistically significant $(\mathrm{P}<0.05)$. That is, WWOX, Elf5 and E-cadherin expression was low in ovarian cancer and highly expressed in adjacent tissues; Snaill, N-cadherin and vimentin were highly expressed in ovarian cancer and had low expression in adjacent tissues (Table I).

Relationship between the expressions of WWOX, Elf5, Snaill and EMT related proteins and clinicopathological parameters. Expression of WWOX, Elf5, Snail1 and EMT-related proteins in epithelial ovarian cancer were correlated with clinical stage, pathological grade and lymph node metastasis $(\mathrm{P}<0.05)$, but not related to age and pathological type $(\mathrm{P}>0.05)$. The later the clinical stage of EOC patients, the higher the pathological grade and the greater the lymph node metastasis and the lower the positive expression rate of WWOX, Elf5 and E-cadherin protein. The difference was statistically significant $(\mathrm{P}<0.05)$ (Tables II-VII).

Correlation of WWOX, Elf5, Snaill and EMT-related protein expression in EOC tissues. The expression levels of 

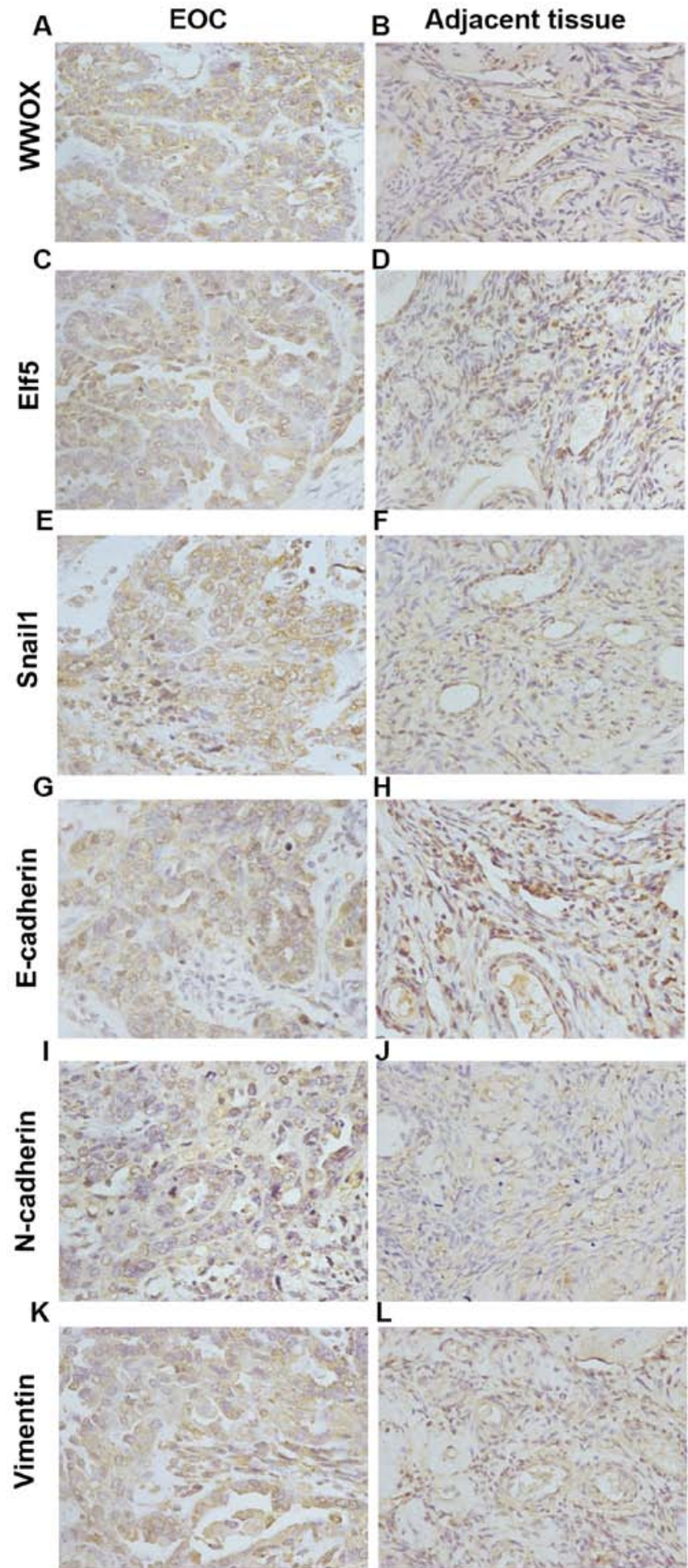

Figure 1. WWOX, Elf5, Snail1 and EMT-related protein expression in EOC tissues and adjacent normal tissues. (A) Low expression of WWOX in EOC (x400). (B) High expression of WWOX in adjacent tissues (x400). (C) Low expression of Elf5 in EOC (x400). (D) High expression of Elf5 in adjacent tissues (x400). (E) High expression of Snaill in EOC (x400). (F) Low expression of Snaill in adjacent tissues (x400). (G) Low expression of E-cadherin in EOC $(x 400)$. (H) High expression of E-cadherin in adjacent tissues ( $x 400)$. (I) High expression of $\mathrm{N}$-cadherin in EOC (x400). (J) Low expression of $\mathrm{N}$-cadherin in adjacent tissues $(\mathrm{x} 400)$. (K) High expression of vimentin in EOC (x400). (L) Low expression of vimentin in adjacent tissues (x400). WWOX, WW domain-containing oxidoreductase; EMT, epithelial-mesenchymal transition; EOC, epithelial ovarian cancer.

WWOX, Elf5, Snail1 and EMT markers in tissue sections of 300 patients with epithelial ovarian cancer were compared.

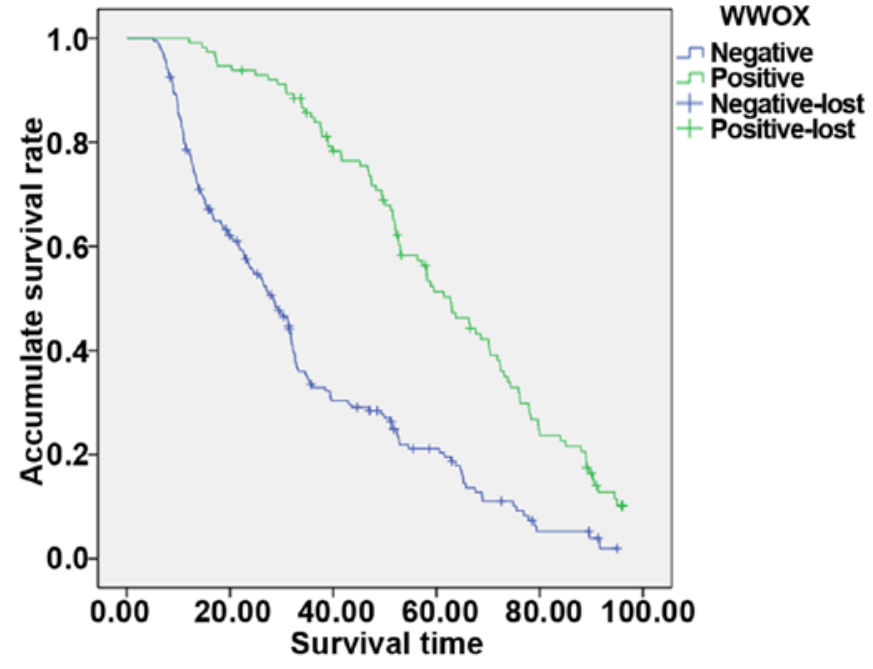

Figure 2. The 5-year survival rates of WWOX protein positive and negative groups. Lost cases are patients who cannot be reached, and those whose died of an accident (such as a car accident) or other illness (such as cardiovascular and cerebrovascular). Positive-lost, the lost cases with positive factor expression. Negative-lost, the lost cases with negative factor expression. WWOX, WW domain-containing oxidoreductase.

The relationship between WWOX and Elf5 expression, the relationship between WWOX and Snaill and EMT marker molecules, the relationship between Elf5 and Snail1 and EMT marker molecule expression were observed. The McNemar test was used to analyze the above relationships: The expression of WWOX and Elf5 was consistent $(\mathrm{P}>0.05)$; the expression of WWOX was significantly different from those of Snaill, N-cadherin and vimentin $(\mathrm{P}<0.05)$, and the expressions of WWOX and E-cadherin had consistency $(\mathrm{P}>0.05)$; the expression of Elf5 was significantly different from those of Snaill, N-cadherin and vimentin $(\mathrm{P}<0.05)$, and the expression of Elf5 and E-cadherin was consistent $(\mathrm{P}>0.05)$, and the difference was statistically significant. The results suggest that the deletion of WWOX and Elf5 in epithelial ovarian cancer may promote the occurrence of Snaill-mediated EMT, which leads to the occurrence and development of epithelial ovarian cancer (Tables VIII-IX).

Survival analysis. The average 5-year survival rate of this group of patients was $22.3 \%$. Forty-four patients were lost to follow-up. Kaplan-Meier survival analysis showed that patients with positive expression of WWOX and Elf5 had higher 5-year survival rate than patients with negative expression. The 5-year survival rates in WWOX protein positive group and WWOX protein negative group were 42.5 and $15.5 \%$, respectively, and the difference was statistically significant $(\mathrm{P}<0.05 ;$ Fig. 2). The 5-year survival rates in Elf5 protein positive group and Elf5 protein negative group were 46.3 and $9.9 \%$. The difference was statistically significant ( $\mathrm{P}<0.05$; Fig. 3). The statistical results showed that the prognosis of patients with positive WWOX expression was better than that of negative patients. The prognosis of patients with positive expression of Elf5 was better than that of negative patients, suggesting that WWOX and Elf5 were protective factors for epithelial ovarian cancer and can be used as indicators to judge the prognosis of patients. 
Table I. Expression of different proteins in ovarian cancer and adjacent normal tissues.

\begin{tabular}{|c|c|c|c|c|c|}
\hline Protein & Group & $\begin{array}{c}\text { Total number of } \\
\text { cases }(n)\end{array}$ & $\begin{array}{l}\text { Positive } \\
\text { (case) }\end{array}$ & $\begin{array}{l}\text { Negative } \\
\text { (case) }\end{array}$ & $\begin{array}{c}\text { Positive rate } \\
(\%)\end{array}$ \\
\hline \multirow[t]{2}{*}{ WWOX } & Ovarian cancer group & 300 & 113 & 187 & 37.7 \\
\hline & Adjacent tissue group & 300 & 264 & 36 & 88.0 \\
\hline \multirow[t]{2}{*}{ Elf5 } & Ovarian cancer group & 300 & 108 & 192 & 36.0 \\
\hline & Adjacent tissue group & 300 & 263 & 37 & 87.7 \\
\hline \multirow[t]{2}{*}{ Snail1 } & Ovarian cancer group & 300 & 199 & 101 & 66.3 \\
\hline & Adjacent tissue group & 300 & 27 & 273 & 9.0 \\
\hline \multirow[t]{2}{*}{ E-cadherin } & Ovarian cancer group & 300 & 91 & 209 & 30.3 \\
\hline & Adjacent tissue group & 300 & 240 & 60 & 80.0 \\
\hline \multirow[t]{2}{*}{ N-cadherin } & Ovarian cancer group & 300 & 154 & 146 & 51.3 \\
\hline & Adjacent tissue group & 300 & 42 & 258 & 14.0 \\
\hline \multirow[t]{2}{*}{ Vimentin } & Ovarian cancer group & 300 & 196 & 104 & 65.3 \\
\hline & Adjacent tissue group & 300 & 24 & 276 & 8.0 \\
\hline
\end{tabular}

WWOX, WW domain-containing oxidoreductase.

Table II. Correlation between WWOX expression and clinicopathological parameters in epithelial ovarian cancer.

\begin{tabular}{|c|c|c|c|c|c|c|}
\hline \multirow{2}{*}{$\begin{array}{l}\text { Clinicopathological } \\
\text { parameters }\end{array}$} & \multirow{2}{*}{$\begin{array}{l}\text { Total number } \\
\text { of cases (n) }\end{array}$} & \multicolumn{2}{|c|}{ WWOX expression } & \multirow{2}{*}{$\begin{array}{l}\text { Positive } \\
\text { rate }(\%)\end{array}$} & \multirow[b]{2}{*}{$\chi^{2}$ value } & \multirow[b]{2}{*}{ P-value } \\
\hline & & Negative & Positive & & & \\
\hline \multicolumn{7}{|l|}{ Age (years) } \\
\hline$<53$ & 154 & 95 & 59 & 38.3 & \multirow[t]{2}{*}{0.056} & \multirow[t]{2}{*}{0.813} \\
\hline$\geq 53$ & 146 & 92 & 54 & 37.0 & & \\
\hline \multicolumn{7}{|l|}{ Pathological type } \\
\hline Serous carcinoma & 168 & 104 & 64 & 38.1 & \multirow[t]{4}{*}{0.194} & \multirow[t]{4}{*}{0.978} \\
\hline Mucinous carcinoma & 63 & 39 & 24 & 38.1 & & \\
\hline Endometrial carcinoma & 54 & 35 & 19 & 35.2 & & \\
\hline Clear cell carcinoma & 15 & 9 & 6 & 40.0 & & \\
\hline \multicolumn{7}{|l|}{ FIGO staging } \\
\hline $\mathrm{I}-\mathrm{II}$ & 143 & 75 & 68 & 47.6 & \multirow[t]{2}{*}{11.374} & \multirow[t]{2}{*}{0.001} \\
\hline III-IV & 157 & 112 & 45 & 28.7 & & \\
\hline \multicolumn{7}{|l|}{ Pathological staging } \\
\hline $\mathrm{G} 1+\mathrm{G} 2$ & 124 & 59 & 65 & 52.4 & \multirow[t]{2}{*}{19.593} & \multirow[t]{2}{*}{$<0.001$} \\
\hline G3 & 176 & 128 & 48 & 27.3 & & \\
\hline \multicolumn{7}{|l|}{ Lymph node metastasis } \\
\hline Yes & 186 & 134 & 52 & 28.0 & \multirow[t]{2}{*}{19.654} & \multirow[t]{2}{*}{$<0.001$} \\
\hline No & 114 & 53 & 61 & 53.5 & & \\
\hline
\end{tabular}

WWOX, WW domain-containing oxidoreductase.

Cox multivariate regression analysis. The age of EOC patients (divided into aged $\geq 53$ years group and $<53$ years group), pathological type (serous cancer group, mucinous cancer group, endometrial cancer group, clear cell cancer group), FIGO stage (divided into I + II group and II + IV group), pathological grade ( $\mathrm{G} 1+\mathrm{G} 2$ group and $\mathrm{G} 3$ group), lymph node metastasis (divided into metastasis group and non-metastasis group), WWOX expression (divided into positive group and negative group), Elf5 expression (divided into positive and negative groups) and other factors were introduced into the Cox multivariate model. The results showed that WWOX, Elf5, FIGO stage, pathological grade and lymph node metastasis were independent factors affecting the prognosis of EOC patients (Table X). 
Table III. Correlation between Elf5 expression and clinicopathological parameters in epithelial ovarian cancer.

\begin{tabular}{|c|c|c|c|c|c|c|}
\hline \multirow{2}{*}{$\begin{array}{l}\text { Clinicopathological } \\
\text { parameters }\end{array}$} & \multirow{2}{*}{$\begin{array}{l}\text { Total number } \\
\text { of cases }(n)\end{array}$} & \multicolumn{2}{|c|}{ Elf5 expression } & \multirow{2}{*}{$\begin{array}{l}\text { Positive } \\
\text { rate }(\%)\end{array}$} & \multirow[b]{2}{*}{$\chi^{2}$ value } & \multirow[b]{2}{*}{ P-value } \\
\hline & & Negative & Positive & & & \\
\hline \multicolumn{7}{|l|}{ Age (years) } \\
\hline$<53$ & 154 & 99 & 55 & 35.7 & 0.011 & 0.916 \\
\hline$\geq 53$ & 146 & 93 & 53 & 36.3 & & \\
\hline \multicolumn{7}{|l|}{ Pathological type } \\
\hline Serous carcinoma & 168 & 106 & 62 & 36.9 & 0.153 & 0.985 \\
\hline Mucinous carcinoma & 63 & 41 & 22 & 34.9 & & \\
\hline Endometrial carcinoma & 54 & 35 & 19 & 35.2 & & \\
\hline Clear cell carcinoma & 15 & 10 & 5 & 33.3 & & \\
\hline \multicolumn{7}{|l|}{ FIGO staging } \\
\hline I-II & 143 & 78 & 65 & 45.6 & 10.601 & 0.001 \\
\hline III-IV & 157 & 114 & 43 & 27.4 & & \\
\hline \multicolumn{7}{|l|}{ Pathological staging } \\
\hline $\mathrm{G} 1+\mathrm{G} 2$ & 124 & 62 & 62 & 50.0 & 17.981 & $<0.001$ \\
\hline G3 & 176 & 130 & 46 & 26.1 & & \\
\hline \multicolumn{7}{|l|}{ Lymph node metastasis } \\
\hline Yes & 186 & 137 & 49 & 26.3 & 19.808 & $<0.001$ \\
\hline No & 114 & 55 & 59 & 51.8 & & \\
\hline
\end{tabular}

Table IV. Correlation between Snail1 expression and clinicopathological parameters in epithelial ovarian cancer.

\begin{tabular}{|c|c|c|c|c|c|c|}
\hline \multirow{2}{*}{$\begin{array}{l}\text { Clinicopathological } \\
\text { parameters }\end{array}$} & \multirow{2}{*}{$\begin{array}{l}\text { Total number } \\
\text { of cases (n) }\end{array}$} & \multicolumn{2}{|c|}{ Snail1 expression } & \multirow{2}{*}{$\begin{array}{l}\text { Positive } \\
\text { rate }(\%)\end{array}$} & \multirow[b]{2}{*}{$\chi^{2}$ value } & \multirow[b]{2}{*}{ P-value } \\
\hline & & Negative & Positive & & & \\
\hline \multicolumn{7}{|l|}{ Age (years) } \\
\hline$<53$ & 154 & 51 & 103 & 66.9 & 0.043 & 0.836 \\
\hline$\geq 53$ & 146 & 50 & 96 & 65.8 & & \\
\hline \multicolumn{7}{|l|}{ Pathological type } \\
\hline Serous carcinoma & 168 & 55 & 113 & 67.2 & 0.166 & 0.983 \\
\hline Mucinous carcinoma & 63 & 22 & 41 & 65.1 & & \\
\hline Endometrial carcinoma & 54 & 19 & 35 & 64.8 & & \\
\hline Clear cell carcinoma & 15 & 5 & 10 & 66.7 & & \\
\hline \multicolumn{7}{|l|}{ FIGO staging } \\
\hline I-II & 143 & 64 & 79 & 55.2 & 15.044 & $<0.001$ \\
\hline III-IV & 157 & 37 & 120 & 76.4 & & \\
\hline \multicolumn{7}{|l|}{ Pathological staging } \\
\hline $\mathrm{G} 1+\mathrm{G} 2$ & 124 & 72 & 52 & 41.9 & 56.338 & $<0.001$ \\
\hline G3 & 176 & 29 & 147 & 83.5 & & \\
\hline \multicolumn{7}{|l|}{ Lymph node metastasis } \\
\hline Yes & 186 & 32 & 154 & 82.8 & 59.399 & $<0.001$ \\
\hline No & 114 & 69 & 45 & 39.5 & & \\
\hline
\end{tabular}

\section{Discussion}

Ovarian cancer is one of the three major malignant tumors in the female reproductive system. Most of the cases are advanced when observed, and the current clinical and other treatments cannot significantly improve the prognosis of patients with ovarian cancer, so the mortality rate of ovarian cancer remains high (4). Although molecular targeted therapy has achieved certain therapeutic effects, there is no systematic theoretical explanation for the pathogenesis of ovarian cancer. Therefore, an in-depth study of the mechanism of ovarian cancer is conducive to providing more 
Table V. Correlation between E-cadherin expression and clinicopathological parameters in epithelial ovarian cancer.

\begin{tabular}{|c|c|c|c|c|c|c|}
\hline \multirow{2}{*}{$\begin{array}{l}\text { Clinicopathological } \\
\text { parameters }\end{array}$} & \multirow{2}{*}{$\begin{array}{l}\text { Total number } \\
\text { of cases (n) }\end{array}$} & \multicolumn{2}{|c|}{ E-cadherin expression } & \multirow{2}{*}{$\begin{array}{l}\text { Positive } \\
\text { rate }(\%)\end{array}$} & \multirow[b]{2}{*}{$\chi^{2}$ value } & \multirow[b]{2}{*}{ P-value } \\
\hline & & Negative & Positive & & & \\
\hline \multicolumn{7}{|l|}{ Age (years) } \\
\hline$<53$ & 154 & 106 & 48 & 31.2 & \multirow[t]{2}{*}{0.105} & \multirow[t]{2}{*}{0.746} \\
\hline$\geq 53$ & 146 & 103 & 43 & 29.5 & & \\
\hline \multicolumn{7}{|l|}{ Pathological type } \\
\hline Serous carcinoma & 168 & 116 & 52 & 31.0 & \multirow[t]{4}{*}{0.139} & \multirow[t]{4}{*}{0.987} \\
\hline Mucinous carcinoma & 63 & 44 & 19 & 30.2 & & \\
\hline Endometrial carcinoma & 54 & 38 & 16 & 29.6 & & \\
\hline Clear cell carcinoma & 15 & 11 & 4 & 26.7 & & \\
\hline \multicolumn{7}{|l|}{ FIGO staging } \\
\hline I-II & 143 & 63 & 80 & 55.9 & \multirow[t]{2}{*}{84.812} & \multirow[t]{2}{*}{$<0.001$} \\
\hline III-IV & 157 & 146 & 11 & 7.0 & & \\
\hline \multicolumn{7}{|l|}{ Pathological staging } \\
\hline $\mathrm{G} 1+\mathrm{G} 2$ & 124 & 50 & 74 & 59.7 & \multirow[t]{2}{*}{86.124} & \multirow[t]{2}{*}{$<0.001$} \\
\hline G3 & 176 & 159 & 17 & 9.7 & & \\
\hline \multicolumn{7}{|l|}{ Lymph node metastasis } \\
\hline Yes & 186 & 158 & 28 & 15.1 & \multirow[t]{2}{*}{54.076} & \multirow[t]{2}{*}{$<0.001$} \\
\hline No & 114 & 51 & 63 & 55.3 & & \\
\hline
\end{tabular}

Table VI. Correlation between N-cadherin expression and clinicopathological parameters in epithelial ovarian cancer.

\begin{tabular}{|c|c|c|c|c|c|c|}
\hline \multirow{2}{*}{$\begin{array}{l}\text { Clinicopathological } \\
\text { parameters }\end{array}$} & \multirow{2}{*}{$\begin{array}{l}\text { Total number } \\
\text { of cases (n) }\end{array}$} & \multicolumn{2}{|c|}{$\mathrm{N}$-cadherin expression } & \multirow{2}{*}{$\begin{array}{l}\text { Positive } \\
\text { rate }(\%)\end{array}$} & \multirow[b]{2}{*}{$\chi^{2}$ value } & \multirow[b]{2}{*}{ P-value } \\
\hline & & Negative & Positive & & & \\
\hline \multicolumn{7}{|l|}{ Age (years) } \\
\hline$<53$ & 154 & 74 & 80 & 51.9 & \multirow[t]{2}{*}{0.048} & \multirow[t]{2}{*}{0.827} \\
\hline$\geq 53$ & 146 & 72 & 74 & 50.7 & & \\
\hline \multicolumn{7}{|l|}{ Pathological type } \\
\hline Serous carcinoma & 168 & 81 & 87 & 51.8 & \multirow[t]{4}{*}{0.211} & \multirow[t]{4}{*}{0.976} \\
\hline Mucinous carcinoma & 63 & 30 & 33 & 52.4 & & \\
\hline Endometrial carcinoma & 54 & 27 & 27 & 50.0 & & \\
\hline Clear cell carcinoma & 15 & 8 & 7 & 46.7 & & \\
\hline \multicolumn{7}{|l|}{ FIGO staging } \\
\hline I-II & 143 & 104 & 39 & 27.3 & \multirow[t]{2}{*}{63.320} & \multirow[t]{2}{*}{$<0.001$} \\
\hline III-IV & 157 & 42 & 115 & 73.2 & & \\
\hline \multicolumn{7}{|l|}{ Pathological staging } \\
\hline $\mathrm{G} 1+\mathrm{G} 2$ & 124 & 88 & 36 & 29.0 & \multirow[t]{2}{*}{42.078} & \multirow[t]{2}{*}{$<0.001$} \\
\hline G3 & 176 & 58 & 118 & 67.0 & & \\
\hline \multicolumn{7}{|l|}{ Lymph node metastasis } \\
\hline Yes & 186 & 63 & 123 & 66.1 & \multirow[t]{2}{*}{42.891} & \multirow[t]{2}{*}{$<0.001$} \\
\hline No & 114 & 83 & 31 & 27.2 & & \\
\hline
\end{tabular}

effective treatment methods (5). The WWOX gene is a newly discovered tumor suppressor gene. Studies have shown that WWOX can interact with different proteins (such as p73, Ap2, ErbB4 and c-Jun) and can also be involved in many signal transduction pathways, such as the death domain of tumor necrosis factor receptor (TRADD) and tumor necrosis factor receptor-associated factor 2 (TRAF2) mediated apoptotic pathway, thereby inhibiting tumor proliferation and promoting tumor cell apoptosis $(6,7)$. Elf5 is located in the 13-15 region of the short arm of human chromosome 11, 
Table VII. Correlation between vimentin expression and clinicopathological parameters in epithelial ovarian cancer.

\begin{tabular}{|c|c|c|c|c|c|c|}
\hline \multirow{2}{*}{$\begin{array}{l}\text { Clinicopathological } \\
\text { parameters }\end{array}$} & \multirow{2}{*}{$\begin{array}{l}\text { Total number } \\
\text { of cases (n) }\end{array}$} & \multicolumn{2}{|c|}{ Vimentin expression } & \multirow{2}{*}{$\begin{array}{l}\text { Positive } \\
\text { rate }(\%)\end{array}$} & \multirow[b]{2}{*}{$\chi^{2}$ value } & \multirow[b]{2}{*}{ P-value } \\
\hline & & Negative & Positive & & & \\
\hline \multicolumn{7}{|l|}{ Age (years) } \\
\hline$<53$ & 154 & 53 & 101 & 65.6 & \multirow[t]{2}{*}{0.009} & \multirow[t]{2}{*}{0.925} \\
\hline$\geq 53$ & 146 & 51 & 95 & 65.1 & & \\
\hline \multicolumn{7}{|l|}{ Pathological type } \\
\hline Serous carcinoma & 168 & 56 & 112 & 66.7 & \multirow[t]{4}{*}{0.372} & \multirow[t]{4}{*}{0.946} \\
\hline Mucinous carcinoma & 63 & 23 & 40 & 63.5 & & \\
\hline Endometrial carcinoma & 54 & 20 & 34 & 63.0 & & \\
\hline Clear cell carcinoma & 15 & 5 & 10 & 66.7 & & \\
\hline \multicolumn{7}{|l|}{ FIGO staging } \\
\hline I-II & 143 & 85 & 58 & 40.6 & \multirow[t]{2}{*}{74.046} & \multirow[t]{2}{*}{$<0.001$} \\
\hline III-IV & 157 & 19 & 138 & 87.9 & & \\
\hline \multicolumn{7}{|l|}{ Pathological staging } \\
\hline $\mathrm{G} 1+\mathrm{G} 2$ & 124 & 76 & 48 & 38.7 & \multirow[t]{2}{*}{66.148} & \multirow[t]{2}{*}{$<0.001$} \\
\hline G3 & 176 & 28 & 148 & 84.1 & & \\
\hline \multicolumn{7}{|l|}{ Lymph node metastasis } \\
\hline Yes & 186 & 38 & 148 & 79.6 & \multirow[t]{2}{*}{43.802} & \multirow[t]{2}{*}{$<0.001$} \\
\hline No & 114 & 66 & 48 & 42.1 & & \\
\hline
\end{tabular}

Table VIII. Correlation analysis between Elf5 with WWOX, E-cadherin, Snail1, N-cadherin and vimentin.

\begin{tabular}{|c|c|c|c|c|c|}
\hline \multirow[b]{2}{*}{ Analysis variables } & \multicolumn{2}{|c|}{ Elf5 } & \multirow[b]{2}{*}{ Total } & \multirow[b]{2}{*}{$\chi^{2}$ value } & \multirow[b]{2}{*}{ P-value } \\
\hline & Positive & Negative & & & \\
\hline \multicolumn{6}{|l|}{ WWOX } \\
\hline Positive & 61 & 52 & 113 & 0.253 & 0.688 \\
\hline Negative & 47 & 140 & 187 & & \\
\hline Total & 108 & 192 & 300 & & \\
\hline \multicolumn{6}{|l|}{ E-cadherin } \\
\hline Positive & 60 & 31 & 91 & 3.658 & 0.071 \\
\hline Negative & 48 & 161 & 209 & & \\
\hline Total & 108 & 192 & 300 & & \\
\hline \multicolumn{6}{|l|}{ Snail1 } \\
\hline Positive & 15 & 184 & 199 & 29.895 & $<0.001$ \\
\hline Negative & 93 & 8 & 101 & & \\
\hline Total & 108 & 192 & 300 & & \\
\hline \multicolumn{6}{|l|}{$\mathrm{N}$-cadherin } \\
\hline Positive & 22 & 132 & 154 & 9.706 & 0.002 \\
\hline Negative & 86 & 60 & 146 & & \\
\hline Total & 108 & 192 & 300 & & \\
\hline \multicolumn{6}{|l|}{ Vimentin } \\
\hline Positive & 20 & 176 & 196 & 29.333 & $<0.001$ \\
\hline Negative & 88 & 16 & 104 & & \\
\hline Total & 108 & 192 & 300 & & \\
\hline
\end{tabular}

WWOX, WW domain-containing oxidoreductase. 
Table IX. Correlation analysis between WWOX and Snail1, E-cadherin, N-cadherin and vimentin.

\begin{tabular}{|c|c|c|c|c|c|}
\hline \multirow[b]{2}{*}{ Analysis variables } & \multicolumn{2}{|c|}{ WWOX } & \multirow[b]{2}{*}{ Total } & \multirow[b]{2}{*}{$\chi^{2}$ value } & \multirow[b]{2}{*}{ P-value } \\
\hline & Positive & Negative & & & \\
\hline \multicolumn{6}{|l|}{ Snail1 } \\
\hline Positive & 21 & 178 & 199 & 27.393 & $<0.001$ \\
\hline Negative & 92 & 9 & 111 & & \\
\hline Total & 113 & 187 & 300 & & \\
\hline \multicolumn{6}{|l|}{ E-cadherin } \\
\hline Positive & 41 & 50 & 91 & 3.967 & 0.057 \\
\hline Negative & 72 & 137 & 209 & & \\
\hline Total & 113 & 187 & 300 & & \\
\hline \multicolumn{6}{|l|}{$\mathrm{N}$-cadherin } \\
\hline Positive & 23 & 131 & 154 & 7.606 & 0.007 \\
\hline Negative & 90 & 56 & 146 & & \\
\hline Total & 113 & 187 & 300 & & \\
\hline \multicolumn{6}{|l|}{ Vimentin } \\
\hline Positive & 25 & 171 & 196 & 26.598 & $<0.001$ \\
\hline Negative & 88 & 16 & 104 & & \\
\hline Total & 113 & 187 & 300 & & \\
\hline
\end{tabular}

WWOX, WW domain-containing oxidoreductase.

Table X. Multivariate analysis of 300 patients with EOC.

\begin{tabular}{lccccccc}
\hline Variable & $\mathrm{B}$ & $\mathrm{SE}$ & Wald & $\mathrm{df}$ & P-value & Exp (B) & 95\% CI \\
\hline FIGO staging & 1.015 & 0.191 & 28.129 & 1 & 0.001 & 2.760 & $1.897-4.017$ \\
Pathological grading & 0.745 & 0.152 & 23.985 & 1 & 0.001 & 2.106 & $1.563-2.837$ \\
Lymph node metastasis & 0.455 & 0.190 & 5.726 & 1 & 0.017 & 1.576 & $1.086-2.288$ \\
WWOX & -0.661 & 0.145 & 20.806 & 1 & 0.001 & 0.516 & $0.389-0.686$ \\
Elf5 & -1.399 & 0.161 & 75.121 & 1 & 0.001 & 0.247 & $0.180-0.339$ \\
\hline
\end{tabular}

WWOX, WW domain-containing oxidoreductase.

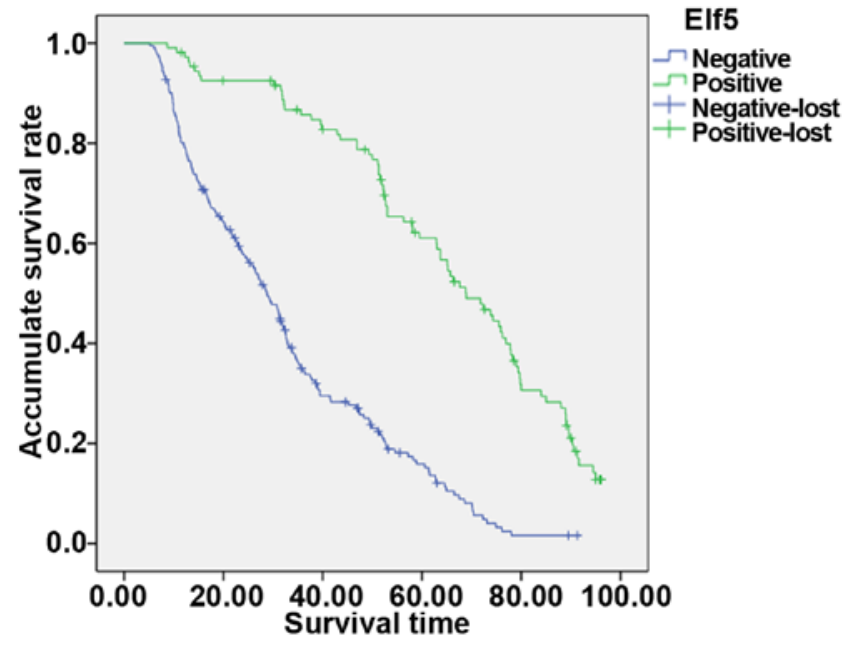

Figure 3. The 5-year survival rates of Elf5 protein positive and negative groups. Lost cases are patients who cannot be reached, and those whose died of an accident (such as a car accident) or other illness (such as cardiovascular and cerebrovascular). Positive-lost, the lost cases with positive factor expression. Negative-lost, the lost cases with negative factor expression. which is prone to loss of heterozygosity in cancer $(8,9)$. Lee and Ormandy (10) showed that the E3 domain of Elf5 is rich in proline and has protein binding function, while the WW1 domain in the WWOX protein binds to a proline-rich domain, and the WWOX protein interacts with the transcription factor Elf5 through this property. The transcription factor Elf5 is not only involved in cell development, differentiation and apoptosis, but also regulates cell proliferation and tumorigenesis (11). Yan et al (12) showed that WWOX mRNA expression in ovarian cancer tissues was lower than that in normal ovarian tissue. Yan et al (11) showed that the expression of Elf5 mRNA in ovarian cancer tissues was lower than that in normal ovarian tissues. In this study, the expression of WWOX and Elf5 in 300 ovarian cancer tissues and adjacent normal tissues were detected by immunohistochemical method. It was found that expression of WWOX and Elf5 was low in ovarian cancer tissues, and highly expressed in adjacent tissues $(\mathrm{P}<0.05)$, indicating that the low expression of WWOX and Elf5 may be closely related to the occurrence of ovarian cancer. 
EMT is a critical step in the development of ovarian cancer invasion, metastasis and drug resistance. It refers to the non-movable polar epithelial cells replaced by movable and migrating interstitial cells under certain special physiological or pathological conditions, and epithelial cells have the phenotype of interstitial cells (13). The occurrence of EMT is regulated by a variety of growth factors and multiple signal transduction pathways. In recent years, the Snaill/E-cadherin signaling pathway has been proven by several studies $(14,15)$. Increased expression of the zinc finger transcription factor Snaill in ovarian cancer can be combined with the E-box promoter on E-cadherin to inhibit the expression of E-cadherin, preventing cells from adhering together, thereby inducing ovarian cancer and causing invasiveness (16). Moreover, EMT mesenchymal markers $\mathrm{N}$-cadherin and vimentin showed increased expression. $\mathrm{N}$-cadherin and vimentin can loosen the tumor cells, resulting in migration and spread $(17,18)$. The results of this study showed that E-cadherin expression was low in EOC tissues and highly expressed in adjacent tissues; Snail1, N-cadherin and vimentin were highly expressed in EOC tissues and the expression was low in adjacent tissues, which was consistent with related studies and the molecular biological characteristics of the EMT process of ovarian cancer.

In this study, it was also concluded that the lower the expression of WWOX and Elf5, the more serious the EMT phenomenon, resulting in invasion and metastasis of ovarian cancer. The higher the pathological grade, the later the surgical pathological stage, the more prone to lymph node metastasis, and the worse the prognosis of patients. In multivariate analysis, the independent influencing factors are relative to the dependent variable (i.e., survival time), not to the independent variable. Given interrelationship between the independent variables, the independent variables (FIGO stage, pathological grade, lymph node metastasis, WWOX and Elf5) were included in a multi-factor regression model.

The results of this study showed that the expression of WWOX and Elf5 in epithelial ovarian cancer tissues was consistent, and the expression may be positively correlated, however, this needs to be confirmed in a future study.

In summary, WWOX acts as a tumor suppressor gene, and the transcription factor Elf5 also has the function as a tumor suppressor gene. The loss of expression of both may promote the EMT phenomenon of ovarian cancer and further promotes the invasion and metastasis of ovarian cancer. WWOX is also expected to be an indicator of early screening for ovarian cancer and a new target for biotherapy. However, the molecular biological mechanism of ovarian cancer is a multi-step, multi-gene regulation process. The specific mechanism as to how the tumor suppressor gene WWOX inhibits EMT in ovarian cancer by Elf5/Snail1 remains to be further studied.

\section{Acknowledgements}

Not applicable.

\section{Funding}

This study was supported by the Natural Science Foundation of Jiangsu Province (no. BK20171182).

\section{Availability of data and materials}

The datasets used and/or analyzed during the present study are available from the corresponding author on reasonable request.

\section{Authors' contributions}

YH wrote the manuscript. YH, YY and YX performed immunohistochemistry. HeY, LF and YL analyzed and interpreted the patient general data. XL, QL and HoY contributed to the analysis of observation indexes. The final version was read and adopted by all the authors. All authors read and approved the final manuscript.

\section{Ethics approval and consent to participate}

The study was approved by the Ethics Committee of Xuzhou No. 1 People's Hospital Affiliated to Xuzhou Medical University and Xuzhou Maternal and Child Health Care Hospital Affiliated to Xuzhou Medical University (Xuzhou, China). Patients who participated in this research, signed an informed consent and had complete clinical data.

\section{Patient consent for publication}

Not applicable.

\section{Competing interests}

The authors declare that they have no competing interests.

\section{References}

1. Siegel RL, Miller KD and Jemal A: Cancer statistics, 2016. CA Cancer J Clin 66: 7-30, 2016.

2. Płuciennik E, Nowakowska M, Pospiech K, Stępień A, Wołkowicz M, Gałdyszyńska M,Popęda M, Wójcik-Krowiranda K, Bieńkiewicz A and Bednarek AK: The role of WWOX tumor suppressor gene in the regulation of EMT process via regulation of CDH1-ZEB1-VIM expression in endometrial cancer. Int $\mathrm{J}$ Oncol 46: 2639-2648, 2015.

3. Gao G and Smith DI: WWOX, large common fragile site genes, and cancer. Exp Biol Med (Maywood) 240: 285-295, 2015.

4. Jayson GC, Kohn EC, Kitchener HC and Ledermann JA: Ovarian cancer. Lancet 384: 1376-1388, 2014.

5. Elzek MA and Rodland KD: Proteomics of ovarian cancer: Functional insights and clinical applications. Cancer Metastasis Rev 34: 83-96, 2015

6. Sałuda-Gorgul A, Seta K, Nowakowska M and Bednarek AK: WWOX oxidoreductase - substrate and enzymatic characterization. Z Naturforsch C J Biosci 66: 73-82, 2011.

7. Abdeen SK,SalahZ, Khawaled S and Aqeilan RI: Characterization of WWOX inactivation in murine mammary gland development. J Cell Physiol 228: 1391-1396, 2013.

8. Omata F, McNamara KM, Suzuki K, Abe E, Hirakawa H, Ishida T, Ohuchi $\mathrm{N}$ and Sasano H: Effect of the normal mammary differentiation regulator ELF5 upon clinical outcomes of triple negative breast cancers patients. Breast Cancer 25: 489-496, 2018.

9. Lapinskas EJ, Svobodova S, Davis ID, Cebon J, Hertzog PJ and Pritchard MA: The Ets transcription factor ELF5 functions as a tumor suppressor in the kidney. Twin Res Hum Genet 14: 316-322, 2011.

10. Lee HJ and Ormandy CJ: Elf5, hormones and cell fate. Trends Endocrinol Metab 23: 292-298, 2012.

11. Yan H, Qiu L, Xie X, Yang H, Liu Y, Lin X and Huang H: ELF5 in epithelial ovarian carcinoma tissues and biological behavior in ovarian carcinoma cells. Oncol Rep 37: 1412-1418, 2017. 
12. Yan HC, Xu J, Fang LS, Qiu YY,Lin XM, Huang HX and Han QY: Ectopic expression of the WWOX gene suppresses stemness of human ovarian cancer stem cells. Oncol Lett 9: 1614-1620, 2015.

13. Brabletz T, Kalluri R, Nieto MA and Weinberg RA: EMT in cancer. Nat Rev Cancer 18: 128-134, 2018.

14. Maturi V, Morén A, Enroth S, Heldin CH and Moustakas A: Genomewide binding of transcription factor Snaill in triple-negative breast cancer cells. Mol Oncol 12: 1153-1174, 2018.

15. Sánchez-Tilló E, Liu Y, de Barrios O, Siles L, Fanlo L, Cuatrecasas M, Darling DS, Dean DC, Castells A and Postigo A: EMT-activating transcription factors in cancer: Beyond EMT and tumor invasiveness. Cell Mol Life Sci 69: 3429-3456, 2012.

16. Palma CS, Grassi ML, Thomé CH, Ferreira GA, Albuquerque D, Pinto MT, Ferreira Melo FU, Kashima S, Covas DT, Pitteri SJ, et al: Proteomic analysis of epithelial to mesenchymal transition (EMT) reveals cross-talk between SNAIL and HDAC1 proteins in breast cancer cells. Mol Cell Proteomics 15: 906-917, 2016.
17. Noh MG, Oh SJ, Ahn EJ, Kim YJ, Jung TY, Jung S, Kim KK, Lee JH, Lee KH and Moon KS: Prognostic significance of E-cadherin and $\mathrm{N}$-cadherin expression in gliomas. BMC Cancer 17: 583, 2017.

18. Li H, Mar BG, Zhang H, Puram RV, Vazquez F, Weir BA, Hahn WC, Ebert B and Pellman D: The EMT regulator ZEB2 is a novel dependency of human and murine acute myeloid leukemia. Blood 129: 497-508, 2017.

This work is licensed under a Creative Commons Attribution-NonCommercial-NoDerivatives 4.0 International (CC BY-NC-ND 4.0) License. 